\title{
The Formation of the Oxides of Carbon by the Pyrolysis of Tobacco*
}

\author{
by R. R. Baker
}

Group Research and Development Centre, British-American Tobacco Co. Ltd., Southampton, England

\section{INTRODUCTION}

It has previously been shown, by smoking a cigarette in an atmosphere of nitrogen and oxygen-18, that about $40 \%$ of the carbon dioxide and $53 \%$ of the carbon monoxide present in mainstream smoke are produced directly from thermal decomposition of the tobacco (I). Furthermore, studies in which the gases inside the combustion coal of a cigarette were analysed (2) have shown that the interior of the coal is effectively an oxygen-deficient pyrolytic region. Within this region, the oxides of carbon appear to be formed in two distinct zones: a high-temperature $\left(500^{\circ}-900^{\circ} \mathrm{C}\right)$ combustion zone and a low-temperature $\left(100^{\circ}-450^{\circ} \mathrm{C}\right)$ pyrolysis zone.

Previous pyrolysis studies have confirmed that the oxides of carbon can be formed from the thermal decomposition of tobacco in an inert atmosphere (2-4). The present study is intended to provide a direct measure of the formation of carbon monoxide and carbon dioxide by the pyrolysis of tobacco as a function of temperature and heating rate, both in an inert atmosphere and in the presence of oxygen.

Received for publication: 16th May, 1974.
Three main approaches have been taken in the present study.

(a) Tobacco has been heated in nitrogen, so that the rates of formation of carbon monoxide and carbon dioxide by thermal decomposition reactions could be determined in isolation.

(b) The solid residue, left after pyrolysis of tobacco in nitrogen, has been heated in air so that the rates of production of carbon oxides by combustion reactions could be determined.

(c) Tobacco has been heated in nitrogen/oxygen mixtures, so that the mutual interaction of pyrolysis and combustion could be determined.

\section{EXPERIMENTAL DETAILS}

\section{Experimental System}

The pyrolysis experiments were carried out under flow conditions, using a reaction furnace constructed from a silica tube (300 $\mathrm{mm}$ long, $8 \mathrm{~mm}$ i. d., $11 \mathrm{~mm} \mathrm{o.} \mathrm{d.)}$ having its central $160 \mathrm{~mm}$ portion evenly wound with $3.5 \mathrm{~m}$ of $6.3 \Omega \mathrm{m}^{-1}$ resistance wire. The experimental system is shown schematically in Figure 1 .

Figure 1. Pyrolysis apparatus (schematic).

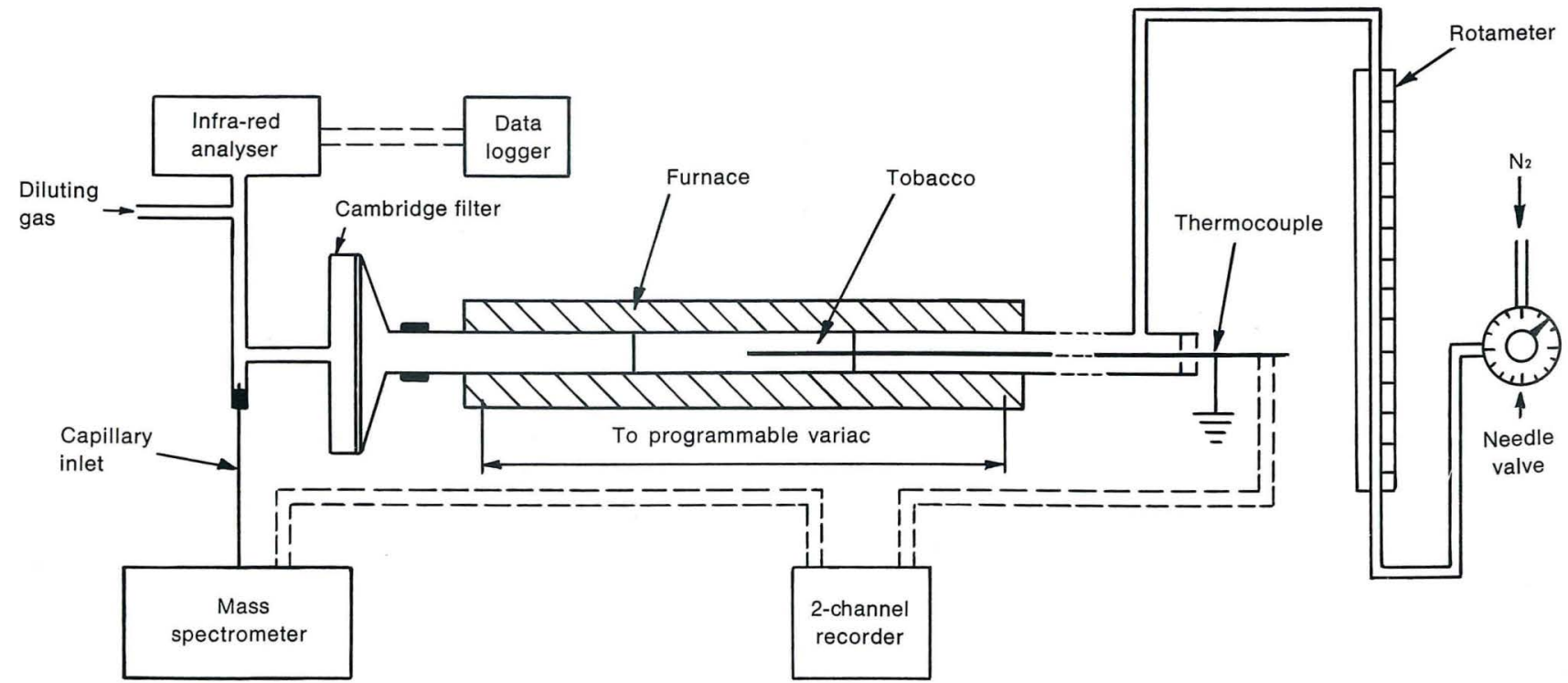


The furnace was heated by connecting its heating coil to the A.C. output of a 10 A Variac. By increasing the Variac output voltage linearly from o $\mathrm{V}$, the furnace could be heated at predetermined rates. A relay circuit was incorporated into the synchrous motor drive to the Variac shaft, such that the power supply was switched off when a pre-set voltage output $(80 \mathrm{~V})$ from the Variac was reached.

By a suitable choice of reduction gears, various heating rates were obtained, but the fastest heating rate ( 12.2 $\operatorname{deg} \mathrm{C} \mathrm{s}^{-1}$ ) could only be obtained by feeding a constant $80 \mathrm{~V}$ to the heating coil of the furnace.

A platinum/platinum - $13 \%$ rhodium thermocouple ( $0.05 \mathrm{~mm}$ diameter wire) was inserted into the tobacco and so directly monitored its temperature during pyrolysis. The thermocouple leads were insulated with fine silica tubing $(0.3 \mathrm{~mm}$ o. d.). The thermocouple was placed inside an earthed metal tube ( $1.6 \mathrm{~mm} \mathrm{o.} \mathrm{d.),}$ which eliminated induction effects in the thermocouple caused by the fluctuating magnetic field created by the alternating current in the heating coil of the furnace.

Tests showed that the axial temperatures in the furnace lay within $\pm{ }_{4}$ deg $C$ of the mean for the temperature range and gas flow conditions used in the present study. Consequently no correction to the thermocouple reading for heat conduction along the thermocouple wire was necessary.

\section{Experimental Procedure}

Since the cigarette paper contributes only $4 \%$ to the total weight of a plain cigarette, and since the tobacco packing density inside the furnace could be kept more nearly constant in different experiments using manufactured cigarettes rather than loosely packed tobacco, plain cigarettes have been pyrolysed. The contributions from the pyrolysis and combustion of the cigarette paper have been assessed in separate experiments, so that all quoted formation rates refer to the tobacco only.

Flue-cured Virginia tobacco has been used throughout the study, conditioned at $21^{\circ} \mathrm{C}$ and $60 \%$ relative humidity, and shown by near infra-red analysis to contain $9.2 \% \mathrm{w} / \mathrm{w}$ water.

"High purity" grade nitrogen (obtained from Air Products Limited, and containing $2-4$ ppm oxygen) was further purified by passing through a furnace containing copper at $800^{\circ} \mathrm{C}$ to remove oxygen impurity, then through a furnace containing copper oxide at $800^{\circ} \mathrm{C}$ to remove hydrogen and hydrocarbons, and finally through a spiral cold trap immersed in solid carbon dioxide $\left(-78^{\circ} \mathrm{C}\right)$ to remove water and other condensable impurities.

The inlet flow of nitrogen (or other gas mixture) into the furnace was kept constant at $3.33 \mathrm{~cm}^{3} \mathrm{~s}^{-1}$. The gases flowing out of the furnace were passed through a Cambridge filter to remove tarry material, and the gas stream was split at a small glass $\mathrm{T}$ junction. One part of the gas flow $\left(0.1 \mathrm{~cm}^{3} \mathrm{~s}^{-1}\right)$ went to the capillary inlet of an A.E.I. MS2 mass spectrometer, where carbon dioxide was analysed, as described previously (2). The other part of the gas flow went directly into the detection cell of a Bosch infra-red analyser (type EFAW 215) for carbon monoxide measurement. In some experiments the gas flow to the Bosch infra-red analyser was diluted with air because the concentration of carbon monoxide in the furnace exit gases often exceeded the full scale deflection of the analyser (10\% $\mathrm{v} / \mathrm{v})$.

A Rikadenki two-channel recorder (model number $241 \mathrm{X}$ ) monitored the outputs from the thermocouple and mass spectrometer, while the output from the infra-red analyser was monitored on a Dynamco data logger (type DM 2022 S). The mass spectrometer was calibrated before and after each experiment, using stanstard carbon dioxide/nitrogen mixtures.

The total outlet flow from the furnace, and the inlet and outlet pressures to the furnace, were measured at room temperature in a separate series of experiments.

In calculating the results, account has been taken of the transit time of the pyrolysis products from their formation region inside the furnace to their point of analysis (3.0 seconds).

With the thermocouple in a given position in the tobacco, each experiment was performed at least twice, and the results averaged. Experiments were always performed under three conditions:

(a) with the thermocouple at the linear and axial centres of the tobacco;

(b) with the thermocouple at the linear centre of the tobacco and I $\mathrm{mm}$ from the furnace wall;

(c) with the thermocouple at the linear and axial centres of the furnace, but with no tobacco present.

\section{Calculation of Product Formation Rate}

The pressure and temperature regions of the flow system are shown schematically in Figure 2.

$V_{\mathrm{N} 1}$ is the flow $\left(\mathrm{cm}^{3} \mathrm{~s}^{-1}\right)$ of carrier gas into the system at temperature $T_{1}\left({ }^{\circ} \mathrm{K}\right)$ and pressure $\mathrm{P}_{1}$ (atmosphere).

$V_{A 2}$ and $V_{B 2}$ are the flows $\left(\mathrm{cm}^{3} \mathrm{~s}^{-1}\right)$ of species $A$ and $B$ into the flow system at temperature $T_{2}$ and pressure $P_{2}$. These represent the rates of formation $\left(\mathrm{cm}^{3} \mathrm{~s}^{-1}\right)$ of species $A$ and $B$ from tobacco in the reaction zone of the furnace, at $T_{2}$ and $P_{2}$.

$V_{D}$ is the flow $\left(\mathrm{cm}^{3} \mathrm{~s}^{-1}\right)$ of a diluting gas into the system at temperature $T_{3}$ and pressure $P_{3}$.

$V_{\text {Tот3 }}$ is the total flow $\left(\mathrm{cm}^{3} \mathrm{~s}^{-1}\right)$ of gases in the flow tube at temperature $T_{3}$ and $P_{3}$, prior to reaching the point of entry of the diluting gas, and is given by:

$$
\mathrm{V}_{\text {TOT3 }}=\mathrm{V}_{\mathrm{A3}}+\mathrm{V}_{\mathrm{B} 3}
$$

where $V_{A 3}$ is the flow $\left(\mathrm{cm}^{3} \mathrm{~s}^{-1}\right)$ of species $A$ at temperature $\mathrm{T}_{3}\left({ }^{\circ} \mathrm{K}\right)$ and pressure $\mathrm{P}_{3}$ (atmospheres), and

Figure 2. Generalised flow system.

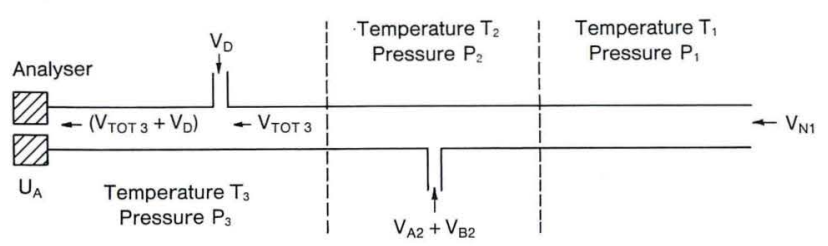


Figure 3. Temperature rise of tobacco heated in nitrogen.
(a) Slow heating rate.
$x$ : Temperature in centre of
wall of furnace.

$\triangle:$ Temperature at wall of furnace.

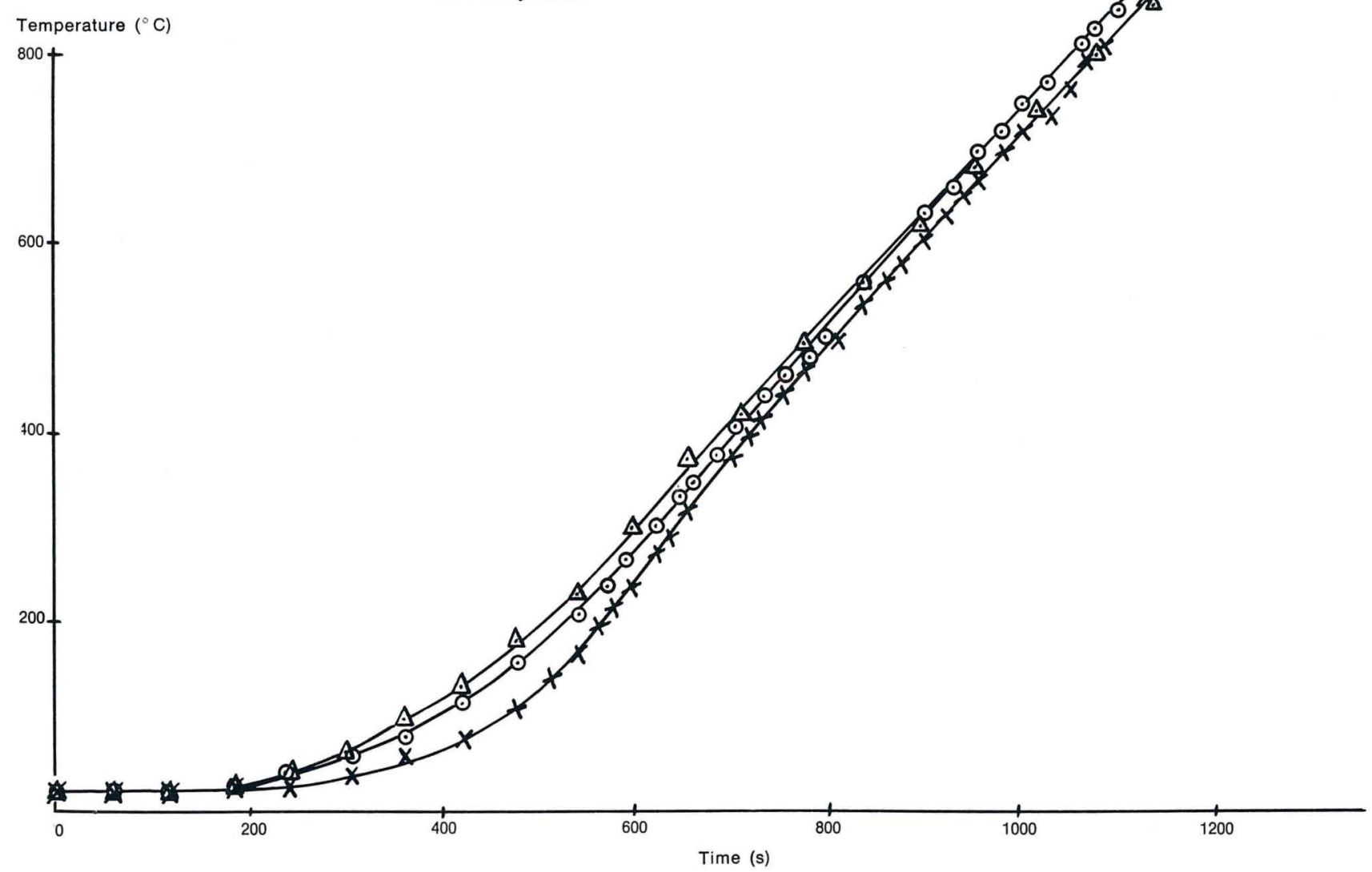

(b) Fast heating rate.

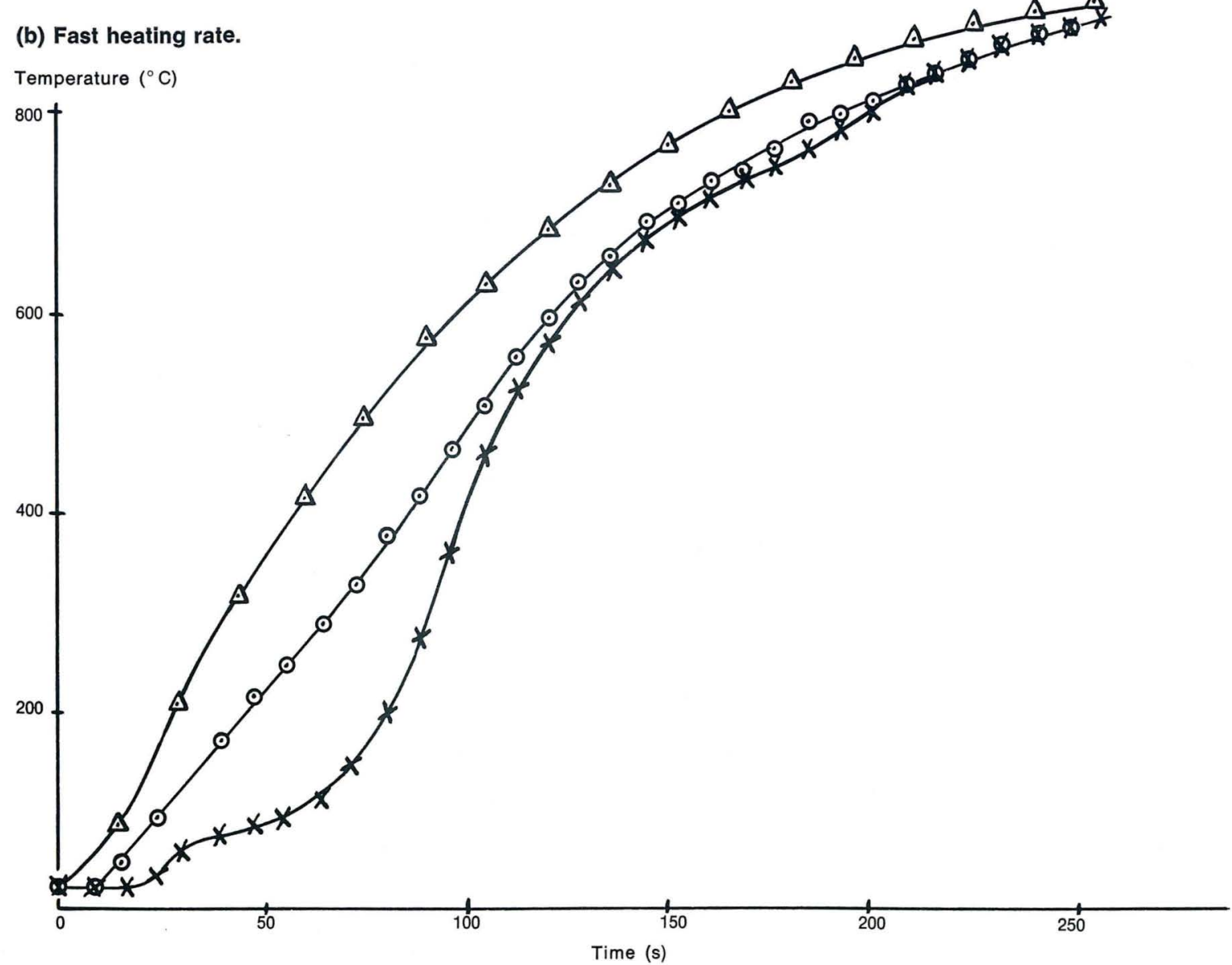


$V_{B 3}$ is the flow $\left(\mathrm{cm}^{3} \mathrm{~s}^{-1}\right)$ of species $B$ at $T_{3}$ and $P_{3}$. $U_{A}$ is the concentration of species $A(\% / v / v)$ as measured at the analysing system at temperature $T_{3}$ and pressure $\mathrm{P}_{3}$.

Thus, $\quad \mathrm{U}_{\mathrm{A}}=\frac{\mathrm{V}_{\mathrm{A} 3}}{\left(\mathrm{~V}_{\mathrm{TOT} 3}+\mathrm{V}_{\mathrm{D}}\right)} 100$.

Consider species $\mathrm{A}$ as an ideal gas (which it will be, since its pressure is always close to atmospheric).

$$
\frac{\mathrm{P}_{3} \mathrm{~V}_{\mathrm{A} 3}}{1000 \mathrm{~T}_{3}}=\frac{\mathrm{P}_{2} \mathrm{~V}_{\mathrm{A} 2}}{1000 \mathrm{~T}_{2}}=\mathrm{n}_{\mathrm{A}} \mathrm{R}
$$

where $n_{A}$ is the molar flow of species $A(m o l ~ s-1)$ in the tube, independent of temperature and pressure, and equal to the rate of formation of species $A$ $\left(\mathrm{mol} \mathrm{s}{ }^{-1}\right)$ in the reaction zone (temperature $T_{2}$ and pressure $\mathrm{P}_{2}$ ), and $R$ is the gas constant, equal to 0.08204 atm $1 \mathrm{~mol}^{-1} \mathrm{deg} \mathrm{K}^{-1}$.

Thus, substituting the value of $V_{\mathrm{A} 3}$ from equation $I$ into equation 2 gives:

$$
\mathrm{n}_{\mathrm{A}}=\frac{\mathrm{P}_{3} \mathrm{U}_{\mathrm{A}}\left(\mathrm{V}_{\mathrm{T} 0 \mathrm{~T} 3}+\mathrm{V}_{\mathrm{D}}\right)}{10^{5} \mathrm{RT}_{3}} .
$$

In the experimental system, $\mathrm{T}_{3}$ is room temperature $\left(298^{\circ} \mathrm{K}\right)$ and $\mathrm{P}_{3}$ is never more than $0.3 \%$ above atmospheric pressure. Thus equation 3 becomes:

$$
\mathrm{n}_{\mathrm{A}}=4.07 \times \mathrm{IO}^{-7} \mathrm{U}_{\mathrm{A}}\left(\mathrm{V}_{\mathrm{T} 0 \mathrm{~T} 3}+\mathrm{V}_{\mathrm{D}}\right)
$$

from which the rate of formation of species $A$ $\left(\mathrm{mol} \mathrm{s}^{-1}\right)$ in the reaction zone can be calculated.

\section{RESULTS AND DISCUSSION}

\section{The Pyrolysis of Tobacco in Nitrogen}

The increase in temperature of $1.00 \pm 0.01 \mathrm{~g}$ of fluecured Virginia tobacco, when heated in nitrogen under flow conditions (inlet flow $=3.33 \mathrm{~cm}^{3} \mathrm{~s}^{-1}$ ) at two heating rates, is shown in Figure 3. These two heating rates will be referred to as the "slow" and "fast" heating rates throughout this paper. Because of the radial temperature distribution in the tobacco samples, subsequent results in this paper refer to the mean tobacco temperature.

Due to the low thermal conductivity of tobacco, the centre of the tobacco is cooler than the periphery at any time. The effect is most pronounced at the fast heating rate, where the temperature in the centre of the tobacco can be almost $180^{\circ} \mathrm{C}$ lower than the temperature at the side of the sample. For the temperatures up to about $100^{\circ} \mathrm{C}$ most of the heat supplied to the interior of the tobacco is absorbed in evaporating the water from the tobacco strands. At temperatures above about $600^{\circ} \mathrm{C}$, the rates of temperature rise at the two positions in the tobacco are similar. In this reaction region, the charred tobacco closely resembles carbon in appearance and is radially homogeneous with respect to thermal diffusivity.

At the slow heating rate, where thermal equilibrium is nearer to being attained throughout the tobacco sample, the three temperature-time curves are much closer together.

The average rate of temperature increase of the tobacco sample above $100^{\circ} \mathrm{C}$ in the slow heating experiments is $1.1 \mathrm{deg} \mathrm{C} \mathrm{s}^{-1}$ throughout the tobacco. In the fast heating experiments, the rate of temperature increase depends on the position in the tobacco, and the temperature region. The maximum rate (12.2 deg $\mathrm{C} \mathrm{s}^{-1}$ ) occurs in the centre of the tobacco between $150^{\circ}$ and $550^{\circ} \mathrm{C}$.

The volumetric outlet flow from the pyrolysis of the tobacco is shown in Figures 4 and 5 at the slow and fast heating rates respectively. The flows were measured at room temperature. Both flow/temperature curves have maxima at about $300^{\circ} \mathrm{C}$ and $700^{\circ} \mathrm{C}$,

Figure 4. Outlet flow from furnace during pyrolysis of $1 \mathrm{~g}$ of tobacco in nitrogen: slow heating rate.

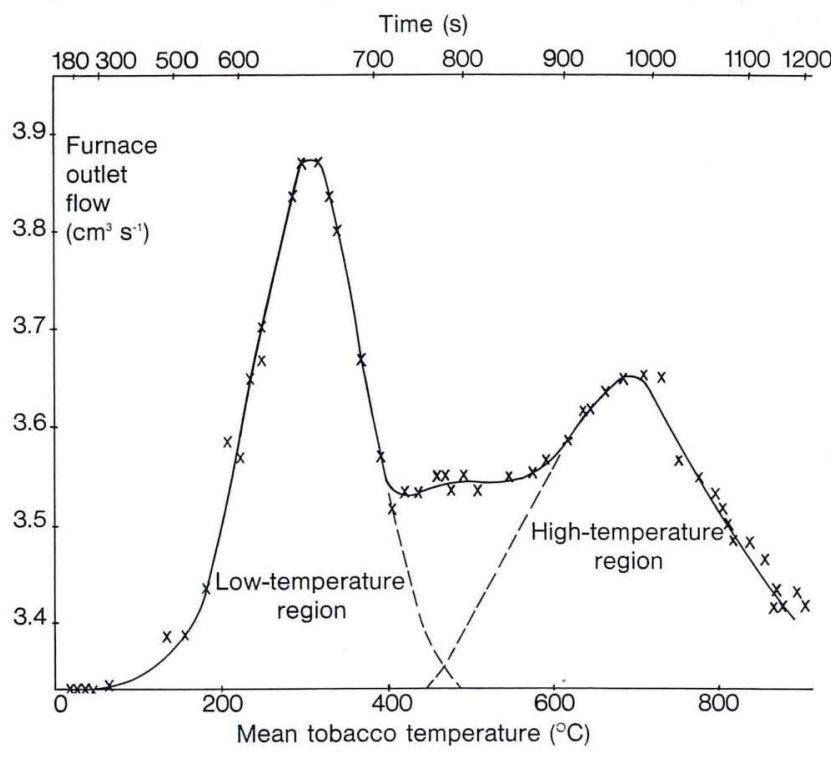

Figure 5. Outlet flow from furnace during pyrolysis of $1 \mathrm{~g}$ of tobacco in nitrogen: fast heating rate.

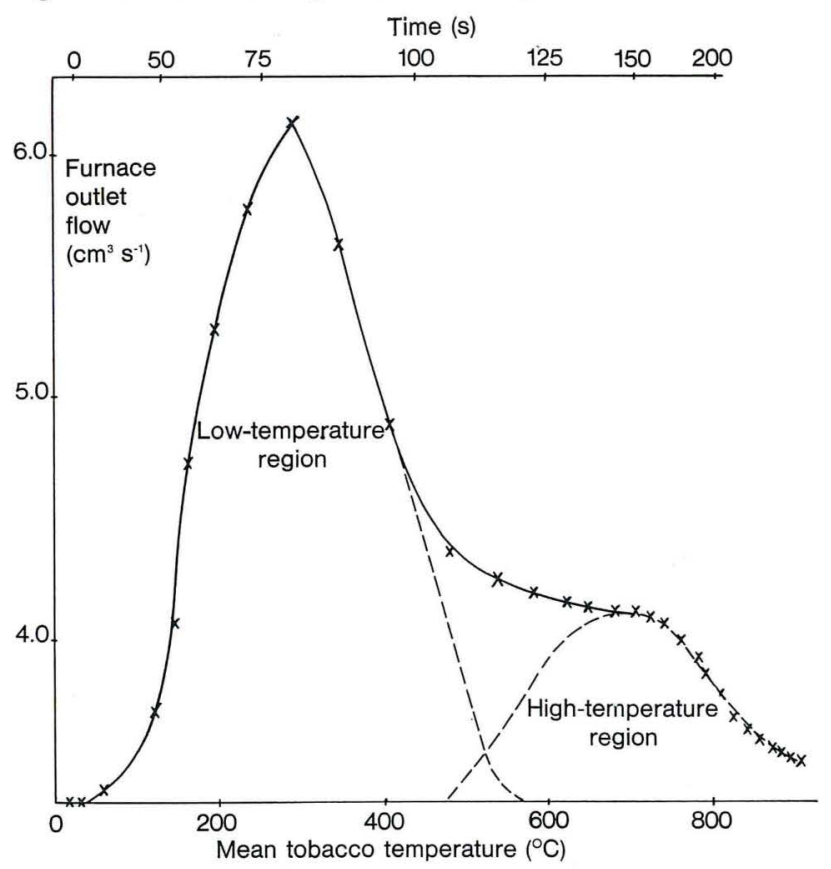


although the second maximum for the fast heating pyrolysis (Figure 5) is not resolved from the first peak, and occurs as a shoulder on the first peak. The curves are qualitatively similar to curves for the rate of weight-loss obtained during the thermogravimetric analysis of tobacco heated in nitrogen at the much slower heating rates of 0.02 to $0.3 \mathrm{deg} \mathrm{C} \mathrm{s}^{-1}(5-7)$. The decomposition reactions giving rise to the general features of the curves in Figures 4 and 5 can be summarised by the conclusions of the thermogravimetric studies.

(a) At $25^{\circ}-150^{\circ} \mathrm{C}$, the evolved gases are mainly due to the desorption of water, together with other low boiling substances.

(b) At $150^{\circ}-220^{\circ} \mathrm{C}$, the evolved gases are due to the loss of hydrated water from the initial decomposition of pectin and sugars.

(c) At $220^{\circ}-350^{\circ} \mathrm{C}$, the evolved gases are due to the volatilisation of leaf constituents such as nicotine, and the decomposition of cellulose and lignin, and low molecular weight polysaccharides and sugars.

(d) Above $550^{\circ} \mathrm{C}$, decomposition of inorganic constituents, such as carbonates and sulphates, occurs.

The outlet pressure (measured at room temperature) varied during the course of the pyrolysis, but never rose by more than $0.3 \%$ above atmospheric pressure.

The Production of Carbon Monoxide und Carbon Dioxide by the Pyrolysis of Tobacco in Nitrogen

The rates of formation of the two oxides of carbon, produced from the pyrolysis of tobacco in purified nitrogen, are shown in Figures 6 and 7 for the slow and fast heating rates respectively. Both figures show that there are two main zones for the production

Figure 6. Production of the oxides of carbon by pyrolysis of $1 \mathrm{~g}$ of tobacco in nitrogen: slow heating rate.

$$
\times: \mathrm{CO}_{2} \quad \odot: \mathrm{CO} \times 2
$$

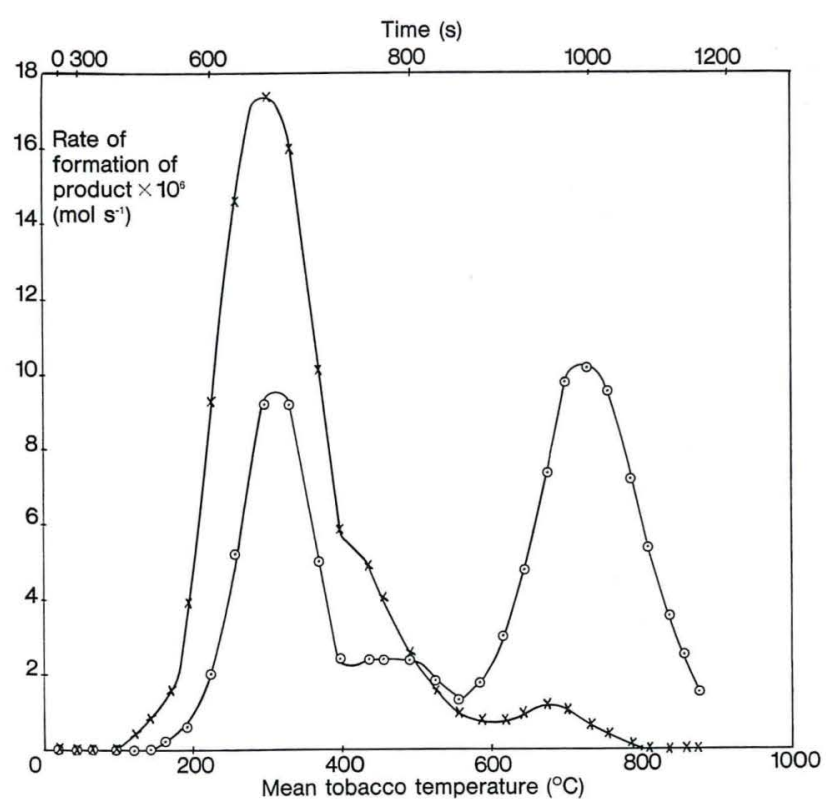

of the oxides: a low-temperature zone (about $100^{\circ}$ to $450^{\circ} \mathrm{C}$, with the maximum rate of production at $250^{\circ}-300^{\circ} \mathrm{C}$ ), and a high-temperature zone (about $550^{\circ}-900^{\circ} \mathrm{C}$, with a maximum rate of production at $\left.720^{\circ} \mathrm{C}\right)$. Carbon dioxide has only a relatively small rate of production in the high-temperature zone. At the slow heating rate (Figure 6), a small and incompletely resolved intermediate formation zone (about $400^{\circ}-500^{\circ} \mathrm{C}$ ) is apparent.

These results confirm the conclusion of previous studies in which cigarettes were smoked under continuous draw conditions (2): a substantial proportion of the oxides of carbon are produced by thermal decomposition of tobacco at $100^{\circ}-450^{\circ} \mathrm{C}$. The well resolved low-temperature production zones in Figures 6 and 7 have virtually identical temperature limits to the zones observed in the previous studies of a burning cigarette. It is also evident that, for carbon monoxide in particular, there must also be some produced by tobacco decomposition in the combustion coal of the cigarette.

The formation of the oxides of carbon by pyrolysis is not sensitised by traces of oxygen. When the tobacco was pyrolysed in unpurified nitrogen (containing 2-4 ppm oxygen), identical curves to those shown in Figures 3-7 (for purified nitrogen) were obtained. This implies that either the pyrolysis is a molecular process, or if free radicals are involved, oxygen does not affect the initiation reactions.

Figure 7. Production of the oxides of carbon by pyrolysis of $\mathbf{1} \mathbf{g}$ of tobacco in nitrogen: fast heating rate.

$\mathrm{X}: \mathrm{CO}$ (left axis scale) $\odot: \mathrm{CO}_{2}$ (right axis scale)

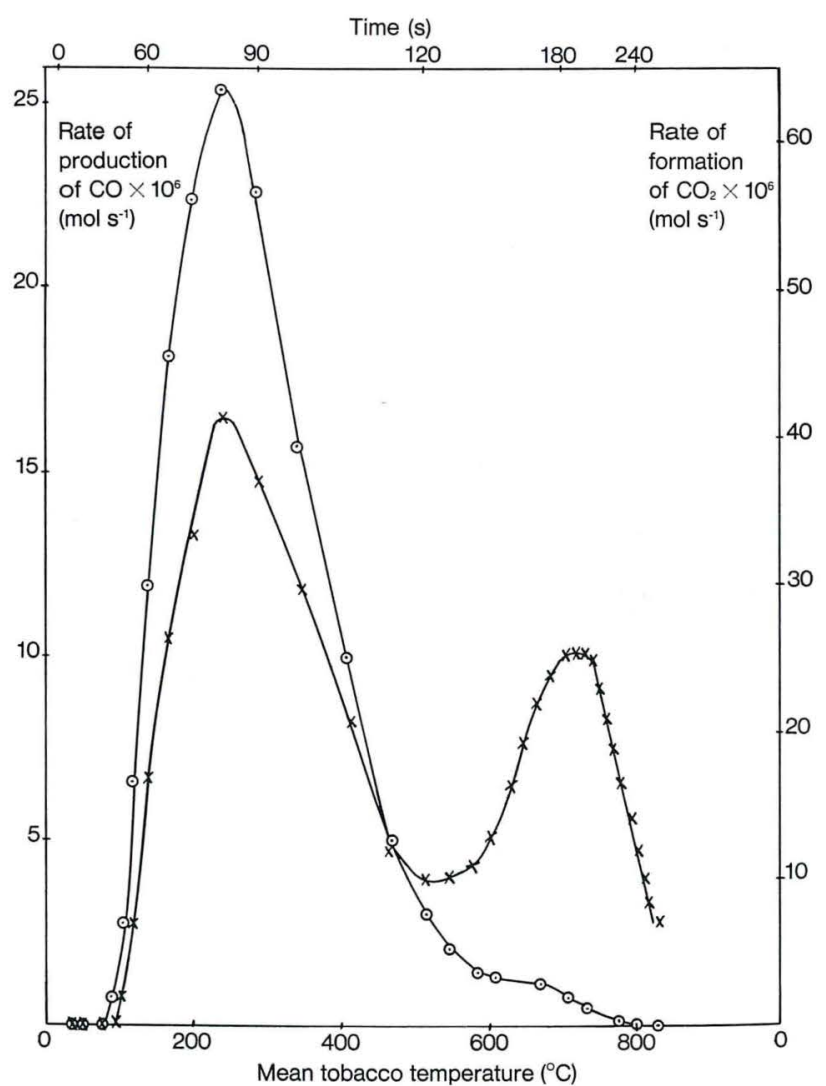


Total Amounts of Products Formed from Tobacco Pyrolysis

The area under the rate of formation/time curve (linear time scaling) gives the total amount of carbon monoxide and dioxide produced throughout the pyrolysis (Tables I and 2). Similarly, the area under the outlet flow/time curves in Figures 4 and 5 gives the total volume of gases evolved, when the origin of the outlet flow axis is set at $3.33 \mathrm{~cm}^{3} \mathrm{~s}^{-1}$ (i.e. equal to the inlet flow of nitrogen). For these area measurements, the tails of the curves have been extrapolated to the base-line axis.
From Tables $x$ and 2 several points are apparent.

(I) The total amount of carbon monoxide produced and the total amount of carbon dioxide produced, are both independent of the heating rate (to within $1 \%$ for carbon monoxide and $5 \%$ for carbon dioxide).

(2) The amounts of carbon dioxide produced in the low-temperature region $\left(100^{\circ}-500^{\circ} \mathrm{C}\right)$, and carbon monoxide produced in the high-temperature region $\left(500^{\circ}-900^{\circ} \mathrm{C}\right)$ are independent of the heating rate (to within $1 \%$ in both cases).

Table 1. Total quantities of carbon monoxide and carbon dioxide produced by heating tobacco in various oxygen/nitrogen gas mixtures ${ }^{+}$.

\begin{tabular}{|c|c|c|c|c|c|c|c|c|c|c|c|}
\hline \multirow[b]{2}{*}{$\begin{array}{l}\text { Sub- } \\
\text { stance } \\
\text { under- } \\
\text { going } \\
\text { reaction }\end{array}$} & \multirow[b]{2}{*}{$\begin{array}{c}\% \mathrm{v} / \mathrm{v} \mathrm{O}_{2} \\
\text { in } \\
\mathrm{N}_{2} / \mathrm{O}_{2}\end{array}$} & \multirow[b]{2}{*}{$\begin{array}{l}\text { Heat- } \\
\text { ing } \\
\text { rate }\end{array}$} & \multicolumn{3}{|c|}{$\mathrm{CO}\left(10^{-6} \mathrm{~mol}\right)$} & \multicolumn{4}{|c|}{$\mathrm{CO}_{2}\left(10^{-6} \mathrm{~mol}\right)$} & \multirow[b]{2}{*}{$\mid \begin{array}{c}\text { Total } \\
\mathrm{CO}+\mathrm{CO}_{2} \\
\left(10^{-6} \mathrm{~mol}\right)\end{array}$} & \multirow[b]{2}{*}{$\begin{array}{l}\text { Total } \\
\text { reaction } \\
\text { time** } \\
\text { (s) }\end{array}$} \\
\hline & & & Total & $\mid \begin{array}{c}\text { Low- } \\
\text { temperature } \\
\text { region } \\
\left(100^{\circ}-500^{\circ} \mathrm{C}\right)\end{array}$ & $\left|\begin{array}{c}\text { High- } \\
\text { temperature } \\
\text { region } \\
\left(500^{\circ}-900^{\circ} \mathrm{C}\right)\end{array}\right|$ & Total & $\mid \begin{array}{c}\text { Low- } \\
\text { temperature } \\
\text { region } \\
\left(100^{\circ}-500^{\circ} \mathrm{C}\right)\end{array}$ & $\begin{array}{c}\text { High- } \\
\text { temperature } \\
\text { region } \\
\left(500^{\circ}-900^{\circ} \mathrm{C}\right)\end{array}$ & $\begin{array}{c}\text { Very high- } \\
\text { temperature } \\
\text { region* } \\
\left(900^{\circ}-1050^{\circ} \mathrm{C}\right)\end{array}$ & & \\
\hline Tobacco & 0 & Slow & 1,772 & 542 & 1,024 & 3,140 & 2,700 & 168 & 0 & 4,912 & 1,280 \\
\hline Tobacco & 0 & Fast & 1,753 & 696 & 1,030 & 2,990 & 2,737 & 218 & 0 & 4,743 & 300 \\
\hline Tobacco & 10 & Slow & 8,615 & 560 & 7,902 & 8,706 & 3,818 & 2,536 & 1,119 & 17,320 & 1,620 \\
\hline Tobacco & 10 & Fast & 11,290 & 711 & 10,580 & 6,404 & 3,729 & 652 & 1,721 & 17,690 & 780 \\
\hline Tobacco & 21 & Slow & 6,098 & 1,137 & 4,961 & 12,540 & 3,301 & 9,240 & 0 & 18,370 & 1,134 \\
\hline Tobacco & 21 & Fast & 9,617 & 1,177 & 8,729 & 9,260 & 4,618 & 1,462 & 2,238 & 18,880 & 408 \\
\hline $\begin{array}{l}\text { Cigarette } \\
\text { Paper++ }\end{array}$ & 0 & Slow & 158 & 76 & 77 & 108 & 66 & 42 & 0 & 266 & 1,280 \\
\hline $\begin{array}{l}\text { Cigarette } \\
\text { Paper++ }\end{array}$ & 0 & Fast & 152 & 72 & 80 & 116 & 78 & 38 & 0 & 268 & 300 \\
\hline $\begin{array}{l}\text { Cigarette } \\
\text { Paper++ }\end{array}$ & 21 & Slow & 156 & 119 & 37 & 623 & 191 & 432 & 0 & 779 & 900 \\
\hline $\begin{array}{l}\text { Cigarette } \\
\text { Paper++ }\end{array}$ & 21 & Fast & 72 & $\phi$ & $\phi$ & 476 & 121 & 355 & 0 & 548 & 130 \\
\hline
\end{tabular}

* This temperature region is only resolved for the $\mathrm{CO}_{2}$ profiles.

** These are the times (s) when the rates of formation of both $\mathrm{CO}$ and $\mathrm{CO}_{2}$ reach zero.

+ Tobacco weight $=1.00 \pm 0.01 \mathrm{~g}$, inlet gas flow to furnace $=3.33 \mathrm{~cm}^{3} \mathrm{~s}^{-1}$.

++ Paper from one plain cigarette $(23-28 \% \mathrm{w} / \mathrm{w}$ chalk loading on paper $)$; weight of paper $=0.040 \mathrm{~g}(=4 \%$ of total cigarette weight).

Table 2. Total volume of evolved gases produced from the pyrolysis of $1 \mathrm{~g}$ of tobacco in various oxygen/nitrogen gas mixtures.

\begin{tabular}{|c|c|c|c|c|c|c|c|}
\hline \multirow[b]{2}{*}{$\begin{array}{c}\% \mathrm{v} / \mathrm{v} \mathrm{O}_{2} \\
\text { in } \\
\mathrm{N}_{2} / \mathrm{O}_{2}\end{array}$} & \multirow[b]{2}{*}{$\begin{array}{l}\text { Heating } \\
\text { rate }\end{array}$} & \multicolumn{6}{|c|}{ Volume of evolved gases $\left(\mathrm{cm}^{3}\right)^{+}$} \\
\hline & & $\begin{array}{c}\text { Net } \\
\text { total } \\
\text { gases }\end{array}$ & $\begin{array}{c}\text { Total } \\
\mathrm{CO}+\mathrm{CO}_{2}\end{array}$ & $\begin{array}{l}\text { Net total } \\
\text { low-temperature } \\
\text { region gases } \\
\left(100^{\circ}-500^{\circ} \mathrm{C}\right)\end{array}$ & $\begin{array}{c}\text { Low-temperature } \\
\mathrm{CO}+\mathrm{CO}_{2}\end{array}$ & $\begin{array}{c}\text { Net total } \\
\text { high-temperature } \\
\text { region gases }{ }^{\star \star} \\
\left(500^{\circ}-1050^{\circ} \mathrm{C}\right)\end{array}$ & $\begin{array}{l}\text { High-temperature } \\
\mathrm{CO}+\mathrm{CO}_{2}\end{array}$ \\
\hline 0 & Slow & 167 & 120 & 75 & 79 & 81 & 29 \\
\hline 0 & Fast & 196 & 116 & 117 & 84 & $62^{*}$ & 30 \\
\hline 10 & Slow & 301 & 423 & 89 & 107 & $182^{*}$ & 282 \\
\hline 10 & Fast & 292 & 432 & 117 & 108 & $175^{\star}$ & 316 \\
\hline 21 & Slow & 207 & 455 & 98 & 108 & $109^{*}$ & 346 \\
\hline 21 & Fast & 255 & 461 & 159 & 141 & $96^{*}$ & 303 \\
\hline
\end{tabular}

+ Calculated to the values at room temperature and pressure.

* Poorly resolved formation region.

** When the carrier gas contains oxygen, the total gases value is the net volume of gases produced, given by:

Net total gases = Total gases produced - Volume of oxygen

$\left(\mathrm{cm}^{3}\right) \quad$ by pyrolysis and consumed in

combustion combustion 
(3) For carbon monoxide in the low-temperature region, and carbon dioxide in the high-temperature region, $29 \pm 5 \%$ more gas is evolved when the tobacco is heated at the fast rate, in both cases. The estimated error on this value is due mainly to the use of two independent deconvolutions. (Note: at the slow heating rate, the carbon oxides produced in the distinct low and high temperature regions account for about $90 \%$ of the total carbon oxides produced. The remainder is produced in an intermediate temperature region. At the fast heating rate, this intermediate region only accounts for $I$ to $2 \%$ of the total oxides produced.)

(4) The major proportion of the carbon monoxide produced by pyrolysis of tobacco ( $58 \%$, independent of heating rate) is formed in the hightemperature region. However, for carbon dioxide, the major proportion (about $89 \%$ ) is formed in the low-temperature region.

(5) In the high-temperature region, only about $40 \%$ of the total gases evolved are accounted for by the oxides of carbon at both heating rates.

(6) In the low-temperature region, $72 \%$ of the evolved gases are accounted for by the oxides of carbon at the fast heating rate, whereas apparently all the evolved gases are accounted for by the oxides of carbon at the slow heating rate (the actual figure being $105 \%$, which reflects the cumulative error of three independent deconvolutions).

(7) Although the paper constitutes only $4 \%$ of the total weight of a plain cigarette, the pyrolysis of paper contributes $9-12 \%$ to the low-temperature carbon monoxide, and $7 \%$ to the hightemperature carbon monoxide, when a cigarette is pyrolysed. The equivalent figures for carbon dioxide are $2-3 \%$ to the low-temperature region, and $15-20 \%$ to the high-temperature region.

The major tobacco decomposition product not accounted for in the high-temperature region is probably hydrogen. Pyrolysis of cane sugar, sugar charcoal, or wood in nitrogen at $1000^{\circ} \mathrm{C}$ shows that the volume of hydrogen produced is very similar to that of carbon monoxide (8). Furthermore, quantities of hydrogen of the same order of magnitude as carbon monoxide have been found in the vicinity of the combustion coal of cigarettes (9). In the low-temperature region, considerable amounts of water will be evolved from the tobacco, and contribute to the total gas phase.

The total amount of carbon monoxide produced in the low-temperature region, and carbon dioxide produced in the high-temperature region, apparently depends on the heating rate. It is probable that carbon monoxide undergoes some gas phase reactions (e.g. reaction with water), and that carbon dioxide undergoes both gas phase reaction (with hydrogen) and heterogeneous reaction (with the carbon char at the higher temperature), and so the ultimate yield and composition of the volatile products will depend in part on the speed with which they are evolved from the solid residue, which will depend partly on the rate at which the solid is heated.

\section{Analytical Results for the Pyrolysis of Tobacco in Nitrogen}

Elemental combustion analysis results for the tobacco and the residues left after pyrolysis in nitrogen, and also for a cigarette coal, are shown in Table 3. The carbon contents of the two pyrolysis residues, and a cigarette coal, are all the same to within $3 \%$ (the coal was obtained by extinguishing a cigarette just after the fourth puff by putting the cigarette into an atmosphere of nitrogen). Since the interior of the coal is an oxygen-deficient high-temperature pyrolysis region (2), an extinguished coal will have been subjected to much the same reaction and temperature history as the tobacco-pyrolysis residue. The maximum rate of temperature increase of the tobacco during the fast pyrolysis is $\mathbf{1 2 . 2} \mathrm{deg} \mathrm{Cs}^{-1}$ (Figure 3), and this corresponds approximately with the rate of temperature rise of tobacco in a cigarette during smoulder (10). The surface areas of the fast pyrolysis residue and a cigarette coal are identical at $12.8 \pm 0.3$ and $12.5 \pm 1.1 \mathrm{~m}^{2} \mathrm{~g}^{-1}$ respectively, which is consistent with the pyrolysed tobacco and the cigarette combustion coal having had similar past histories.

The results in Table 3 show that 0.207 and $0.217 \mathrm{~g}$ of carbon are lost from the tobacco during the slow

Table 3. Analysis of tobacco and pyrolysis residues.

\begin{tabular}{|c|c|c|c|c|c|c|}
\hline \multirow[b]{2}{*}{ Sample } & \multicolumn{5}{|c|}{$\% \mathrm{w} / \mathrm{w}$ of component } & \multirow{2}{*}{$\begin{array}{l}\text { Surface area } \\
\left(\mathrm{m}^{2} \mathrm{~g}^{-1}\right)^{+}\end{array}$} \\
\hline & Water* & $\begin{array}{c}\text { Non-combustible } \\
\text { residue }\end{array}$ & Carbon $^{\varnothing}$ & Hydrogen $\phi$ & Nitrogen $\varnothing$ & \\
\hline Flue-cured tobacco & 9.2 & $12.26++$ & 46.90 & 6.70 & 1.92 & Not measured \\
\hline Tobacco after slow pyrolysis & 0 & 28.20 & 71.19 & 0.74 & 2.21 & Not measured \\
\hline Tobacco after fast pyrolysis & 0 & 27.16 & 69.12 & 0.78 & 2.80 & $12.8 \pm 0.3$ \\
\hline Cigarette coal & 0 & 29.29 & 69.41 & 2.18 & 3.09 & $12.5 \pm 1.1$ \\
\hline
\end{tabular}

* Near infra-red water analysis.

** This is the residue left after the combustion chemical analyses, which were done at the National Physical Laboratory, Teddington. This residue could consist of metal oxides, partly formed by oxidation during the combustion analysis.

+ Measurement done at the National Physical Laboratory, Teddington, by nitrogen B.E.T. adsorption.

++ Quoted as the percentage of non-combustible residue in the hydrous tobacco.

$\varnothing$ Quoted as the percentage of the element present in the organic (combustible) part of the material. 
Table 4. Mass balance of products accounted for from the pyrolysis of tobacco in nitrogen*.

\begin{tabular}{c|c|c|c|c|c}
\hline \multirow{2}{*}{$\begin{array}{c}\text { Heating } \\
\text { rate }\end{array}$} & $\begin{array}{c}\text { Mass balance } \\
\text { of products } \\
\text { collected } \\
(\%)\end{array}$ & $\mathrm{CO}$ & $\mathrm{CO}_{2}$ & T.P.M. & Weight of component $(\mathrm{g})$ \\
\cline { 3 - 6 } & 87.6 & 0.0496 & 0.138 & $0.373 \pm 0.015$ & $\begin{array}{c}\text { Solid residue left } \\
\text { after pyrolysis }\end{array}$ \\
\hline Slow & 88.9 & 0.0491 & 0.132 & $0.407 \pm 0.015$ & $0.315 \pm 0.005$ \\
Fast & & & & $0.301 \pm 0.005$ \\
\hline
\end{tabular}

* Weight of tobacco $=1.00 \pm 0.01 \mathrm{~g}$.

** Mass balance $(\%)=100 \times \sum \frac{\text { (weight of product) }}{\text { weight of original tob }}$

+ The total particulate matter (T.P.M.) was collected on the cooler parts of the furnace, and on two Cambridge filter pad assemblies.

and fast pyrolyses, respectively. The total amounts of carbon oxides evolved during the two pyrolyses are equivalent to 0.0589 and $0.0569 \mathrm{~g}$ of carbon respectively, indicating that the formation of carbon oxides only accounts for a relatively minor proportion (about $27 \%$ ) of the carbon lost from the tobacco. The major proportion of carbon lost must be in the formation of particulate matter.

The mass balance figures in Table 4 show that the products collected from the pyrolysis of tobacco [the carbon oxides, total particulate matter (T.PM.), and the solid carbonaceous residue left after the pyrolysis] account for $88 \%$ of the pyrolysis products.

\section{The Oxidation of Tobacco-Pyrolysis Residue in Air}

The tobacco in a cigarette burns in two stages, leaving inorganic, non-combustible ash as the final solid product. The first stage is the parallel combustion and pyrolysis of both solid tobacco and its volatile products, while the second stage is the burning of the solid carbon residue left after generation and combustion of the volatiles in the first stage.

The black, carbon-like residue of tobacco left after pyrolysis in nitrogen was kept in the pyrolysis tube at about $800^{\circ} \mathrm{C}$ for several minutes, with nitrogen passing over it, until the furnace outlet flow had been identical to the inlet flow for several minutes, to make sure that all the pyrolysis reactions had gone to completion. Experiments were then performed with the pyrolysis-residue used as the reacting solid, and heated at the two heating rates in a stream of air (furnace inlet flow of $3.33 \mathrm{~cm}^{3} \mathrm{~s}^{-1}$ ). Under these conditions, all observed effects would be due solely to combustion.

The increase in temperature of the tobacco pyrolysisresidue when heated in air is shown in Figure 8. The temperature rise is similar to that shown in Figure 3 up to about $200^{\circ}$ C. However, above this temperature the exothermic combustion reactions cause the temperature rise of the reactant to accelerate above that of the furnace. Above about $550^{\circ} \mathrm{C}$, the hottest part of the reactant is its centre, indicating that the exothermic reactions are occurring throughout the body of the solid. The exothermic reactions begin to subside after about 1000 and 200 seconds, at the slow and fast heating rates respectively.

The rates of formation curves for the two oxides of carbon are shown in Figures 9 and 10, for the slow and fast heating rates respectively. Plotted against temperature, the formation curves have slightly positive gradients where the formation rates are decreasing at the highest temperatures, due to the cooling of the reacting system as the exothermic combustion reactions go to completion (Figure 8 ). The carbon dioxide profile

Figure 8. Temperature rise of tobacco-pyrolysis residue heated in air.

$\triangle:$ Wall temperature. $\quad x:$ Temperature in centre of solid. $\odot$ : Temperature in solid, $1 \mathrm{~mm}$ from wall.

(a) Slow heating rate.

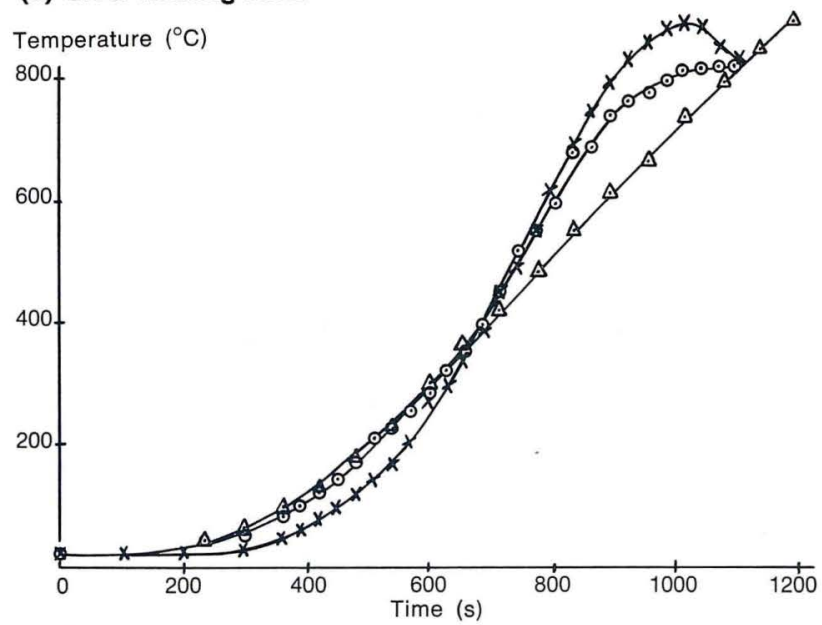

(b) Fast heating rate.

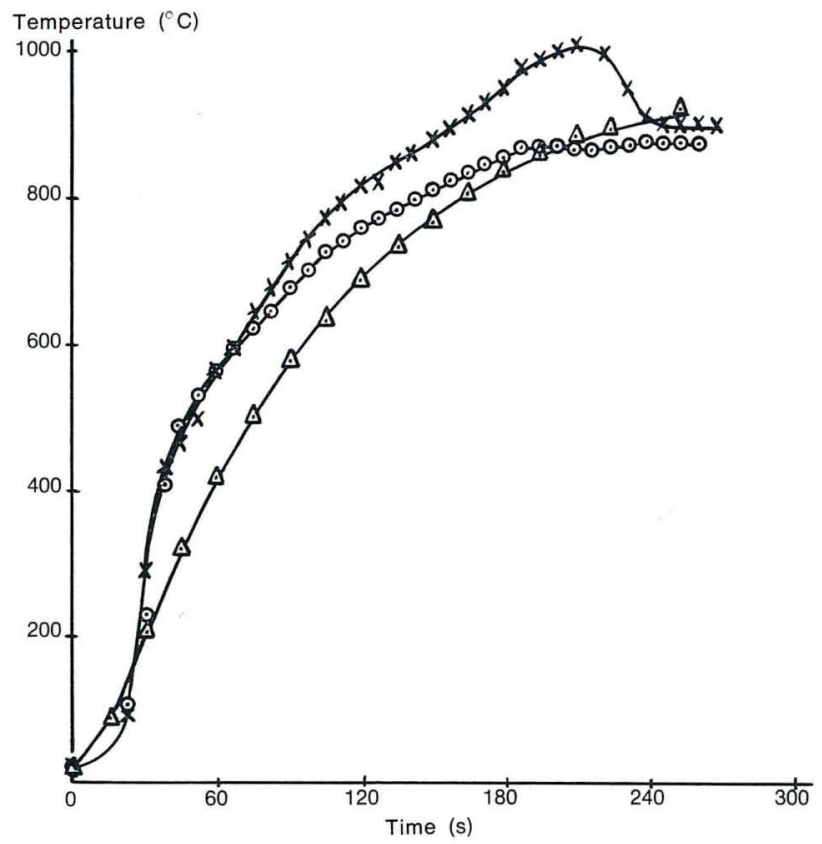


Figure 9. Formation of carbon oxides by heating tobaccopyrolysis residue in air: Slow heating rate.

$$
\odot: \mathrm{CO} \quad \times: \mathrm{CO}_{2} \div 2
$$

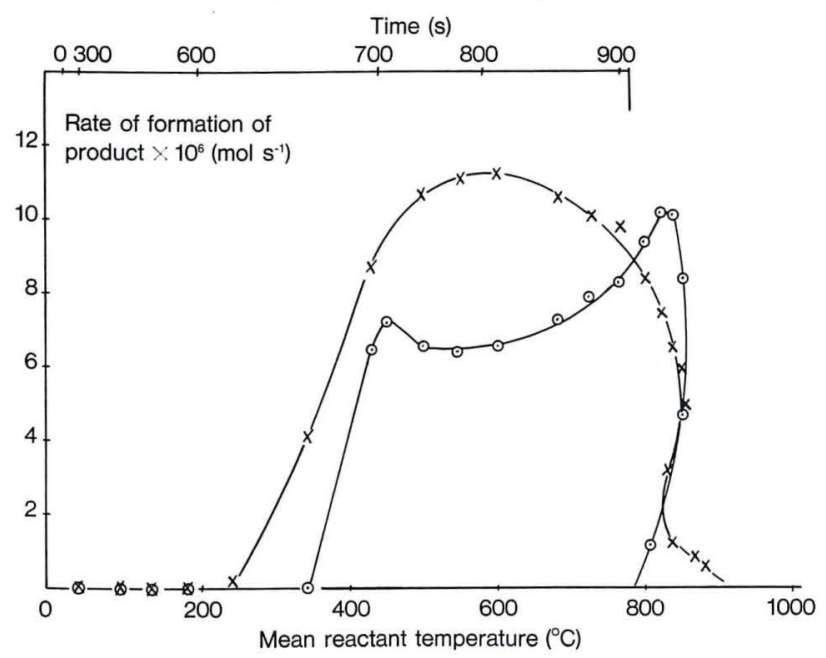

Figure 10. Formation of carbon oxides by heating tobacco-pyrolysis residue in air: fast heating rate.

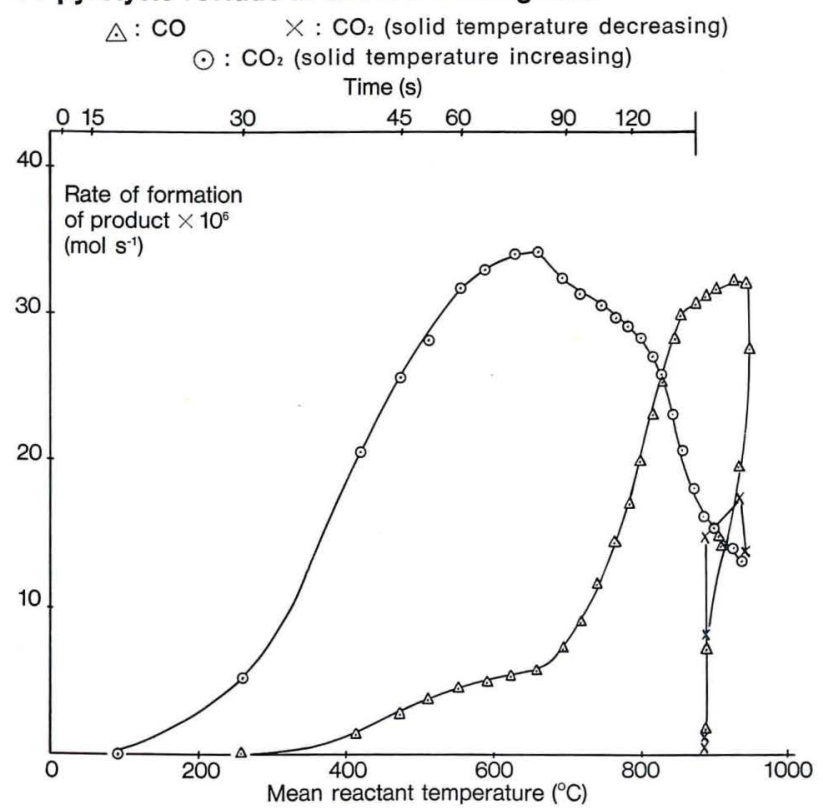

at the fast heating rate shows a distinct very high temperature formation region (about $900^{\circ}-950^{\circ} \mathrm{C}$ ). This region is not adequately defined on the temperature abscissa plot in Figure 10, but is more distinct on the linear-time abscissa plot shown in Figure 11. This region corresponds to the observed decrease in the rate of formation of carbon monoxide and at the high temperatures involved it is almost certainly due to
Figure 11. Formation of carbon oxides by heating tobaccopyrolysis residue in air: fast heating rate.

$$
\odot: \mathrm{CO} \quad \times: \mathrm{CO}_{2}
$$

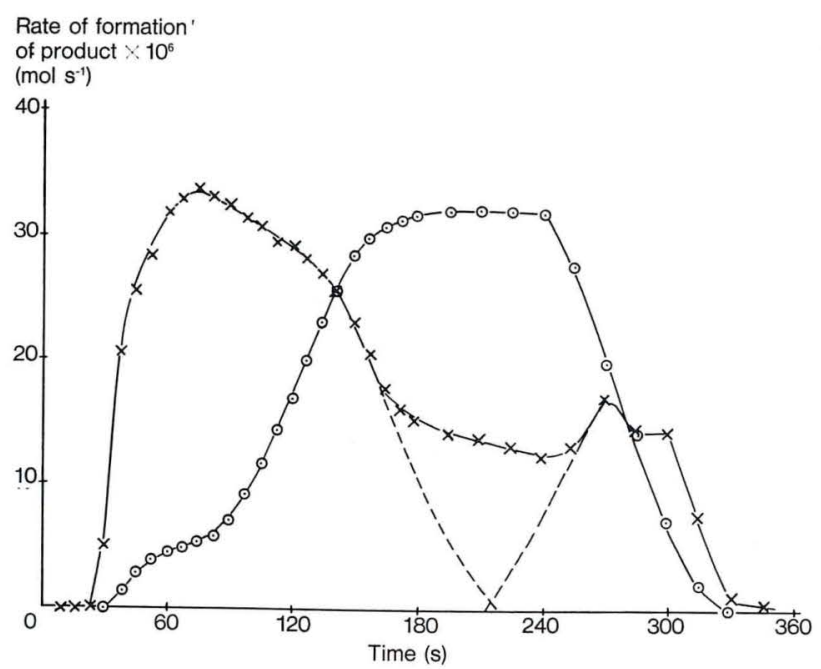

the gas-phase oxidation of carbon monoxide (II), probably in the presence of water and hydroxyl radicals.

The total amounts of carbon monoxide and carbon dioxide produced during the combustion, calculated from the area under the product rate/time curves, are shown in Table 5. The total yield of carbon oxides $\left(\mathrm{CO}+\mathrm{CO}_{2}\right)$ is independent of heating rate (to within $6 \%$ ), although the relative yields of carbon monoxide and dioxide depend on the heating rate. At the slow heating rate, relatively more carbon dioxide, and less carbon monoxide, is produced. Thus at the slow heating rate more complete combustion occurs. This is also reflected in the fact that at the slow heating rate, the net total volume of gases produced is less than at the fast heating rate (Table 5), indicating that at the slow heating rate, more oxygen is consumed in combustion.

The weight of material collected on the Cambridge pad during these combustion experiments was about $0.008 \mathrm{~g}$, and the material collected was almost colourless. This contrasts sharply with the material collected in the pyrolysis and combustion of the original tobacco, when the Cambridge pad had the characteristic brown colour and odour of T.P.M. In the present experiments, the colourless material was probably mainly water. The maximum amount of water that could be produced by combustion of the tobacco-pyrolysis residue (using the analysis figures in

\begin{tabular}{|c|c|c|c|c|c|c|}
\hline \multirow{2}{*}{$\begin{array}{l}\text { Heating } \\
\text { rate }\end{array}$} & \multicolumn{3}{|c|}{ Amount $\left(10^{-6} \mathrm{~mol}\right)$} & \multirow{2}{*}{$\begin{array}{l}\text { Weight of carbon } \\
\text { in carbon oxides } \\
\text { collected } \\
\text { (g) }\end{array}$} & \multirow{2}{*}{$\begin{array}{l}\text { Weight of carbon } \\
\text { in original } \\
\text { solid }\end{array}$} & \multirow{2}{*}{$\begin{array}{l}\text { Net total gases } \\
\text { produced } \\
\left(\mathrm{cm}^{3}\right)\end{array}$} \\
\hline & $\mathrm{CO}$ & $\mathrm{CO}_{2}$ & $\mathrm{CO}+\mathrm{CO}_{2}$ & & & \\
\hline Slow & 3,048 & 7,570 & 10,618 & 0.127 & 0.186 & 30.5 \\
\hline Fast & 5,412 & 5,868 & 11,280 & 0.135 & 0.151 & 49.9 \\
\hline
\end{tabular}

Table 5. Total quantities of gases produced from the combustion of tobacco-pyrolysis residue in air.

\footnotetext{
* When the carrier gas through the furnace contains air, the net total volume of gases produced is equal to the total volume of gases produced by combustion, less the volume of oxygen consumed in combustion.
} 
Table 3) is $0.015 \mathrm{~g}$, indicating that the $0.008 \mathrm{~g}$ of material collected could well be entirely water. The results in Table 5 indicate that the two oxides of carbon account for $68 \%$ and $89 \%$ of the carbon present in the original solid, at the slow and fast heating rates respectively. Thus it would appear that the combustion of tobacco-pyrolysis residue produces carbon monoxide, carbon dioxide and water as the main products.

\section{The Oxidation/Thermal Decomposition of Tobacco in Nitrogen/Oxygen Mixtures}

Oxidation experiments have been carried out in an identical manner to those described for the pyrolysis of tobacco in nitrogen, with a mixture of (a) $10 \%$ oxygen, $90 \%$ nitrogen and (b) air, flowing into the furnace.

The rate of formation curves for the carbon oxides when heated in $10 \%$ oxygen, $90 \%$ nitrogen at the fast heating rate are shown in Figure 12. The curves for the other oxygen/nitrogen mixtures, and heating rates, are fairly similar. The carbon dioxide profiles show distinct very high temperature formation regions $\left(900^{\circ}-1050^{\circ} \mathrm{C}\right)$, as observed in the oxidation of the tobacco-pyrolysis residue. The total quantities of carbon oxides formed are summarised in Table 1 , and in terms of volumes of gases in Table 2 .

Under oxidation conditions, the oxides of carbon are produced in two main temperature regions (about $100^{\circ}-500^{\circ} \mathrm{C}$, and $\left.500^{\circ}-1000^{\circ} \mathrm{C}\right)$. The total yield of carbon oxides $\left(\mathrm{CO}+\mathrm{CO}_{2}\right)$ for a given oxygen content in the carrier gas is independent of heating rate (to within $3 \%$, Table 1). At the end of the oxidation runs, the only solid residue left in the furnace (apart from T.P.M.) was the grey coloured ash (weighing $0.123 \mathrm{~g}$ ). Using the results for total carbon oxides produced (Table 1 ), and the analysis of the original tobacco (Table 3), it is apparent that $57 \%$ and $61 \%$ of the carbon originally present in the tobacco is used in the formation of oxides of carbon, independently of heating rate, when the tobacco is oxidised in $10 \%$ and $21 \%$ oxygen respectively.

The relative proportions of the two oxides of carbon is, however, dependent on heating rate. At the fast
Figure 12. Production of oxides of carbon by oxidation of $1 \mathrm{~g}$ of tobacco in $10 \%$ oxygen, $90 \%$ nitrogen: fast heating rate.

$\odot: \mathrm{CO} \triangle \mathrm{CO}_{2}$ (solid temperature decreasing) $X: \mathrm{CO}_{2}$ (solid temperature increasing)

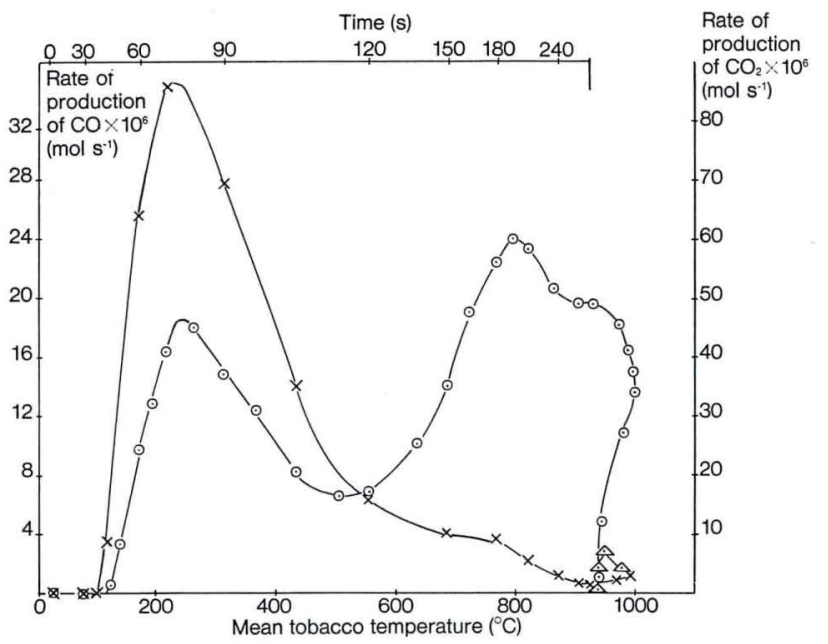

heating rate, $31 \%$ and $58 \%$ more carbon monoxide is produced than at the slow heating rate, when the tobacco is oxidised in $10 \%$ and $21 \%$ oxygen respectively. Proportionately less carbon dioxide is produced at the fast heating rate. Similarly, when the pyrolysis residue is heated in air, the total yield of carbon oxides is independent of heating rate, but $78 \%$ more carbon monoxide is produced at the fast heating rate (Table 5).

The results in Table 2 indicate that in the low-temperature region $\left(100^{\circ}-500^{\circ} \mathrm{C}\right), 76 \%$ and $66 \%$ of the total yield of carbon oxides, approximately independent of heating rate, are produced by thermal decomposition reactions when the tobacco is heated in $10 \%$ and $21 \%$ oxygen respectively. Thus, although some oxidation does occur at these low temperatures, the decomposition reactions are predominant. [The occurrence of low-temperatures oxidation, in the absence of pyrolysis, is illustrated by the heating of pyrolysisresidue in air (Figures 9 and 10), which shows that both carbon monoxide and carbon dioxide are produced at temperatures as low as $300^{\circ} \mathrm{C}$.]

Table 6. Yield of oxides of carbon when tobacco is heated in air relative to yield from independent thermal decomposition and oxidation experiments.

\begin{tabular}{|c|c|c|c|c|c|c|c|}
\hline \multirow{3}{*}{$\begin{array}{l}\text { Heating } \\
\text { rate }\end{array}$} & \multicolumn{7}{|c|}{$\frac{\text { Thermal decomposition yield }+ \text { oxidation yield }}{\text { Observed yield }} \times 100 \%$} \\
\hline & \multicolumn{2}{|c|}{$\begin{array}{l}\text { Low-temperature } \\
\text { region }\left(100^{\circ}-500^{\circ} \mathrm{C}\right)\end{array}$} & \multicolumn{2}{|c|}{$\begin{array}{l}\text { High-temperature }{ }^{* *} \\
\text { region }\left(500^{\circ}-1,050^{\circ} \mathrm{C}\right)\end{array}$} & \multirow[t]{2}{*}{ f (total CO) } & \multirow[t]{2}{*}{$\mathrm{f}\left(\right.$ total $\left.\mathrm{CO}_{2}\right)$} & \multirow{2}{*}{$\begin{array}{c}\mathrm{f}(\text { total } \\
\left.\mathrm{CO}+\mathrm{CO}_{2}\right)\end{array}$} \\
\hline & $f(C O)$ & $\mathrm{f}\left(\mathrm{CO}_{2}\right)$ & $\mathrm{f}(\mathrm{CO})$ & $f\left(\mathrm{CO}_{2}\right)$ & & & \\
\hline Slow & 79 & 106 & 75 & 75 & 79 & 85 & 85 \\
\hline Fast & 93 & 74 & 69 & 145 & 75 & 96 & 85 \\
\hline
\end{tabular}

\footnotetext{
* The thermal decomposition yield is the yield from the pyrolysis in nitrogen experiments (Table 1). The oxidation yield is the yield when the pyrolysis residue is heated in air (Table 5), with low-temperature and high-temperature region yields being approximately estimated from Figures 9-11. The observed yield is the yield when tobacco is heated in air (Table 1).

** Also includes the "very high-temperature" region of Table 1.
} 
Table 7. Proportion of carbon monoxide and carbon dioxide produced by thermal decomposition of tobacco in the high-temperature region* under oxidation conditions.

\begin{tabular}{|c|c|c|c|}
\hline \multirow{3}{*}{$\begin{array}{l}\% \text { v/v } \mathrm{O}_{2} \text { in } \\
\text { carrier gas }\end{array}$} & \multirow{3}{*}{$\begin{array}{c}\text { Heating } \\
\text { rate }\end{array}$} & \multirow{2}{*}{\multicolumn{2}{|c|}{$=\mid \frac{\text { Thermal decomposition } \mathrm{CO}_{\mathrm{x}}}{\text { Total } \mathrm{CO}_{\mathrm{x}}} \times 100 \%$}} \\
\hline & & & \\
\hline & & $p(C O)$ & $\mathrm{p}\left(\mathrm{CO}_{2}\right)$ \\
\hline 10 & Slow & 13.0 & 4.6 \\
\hline 10 & Fast & 9.7 & 9.2 \\
\hline 21 & Slow & 20.6 & 1.8 \\
\hline 21 & Fast & 11.8 & 5.9 \\
\hline
\end{tabular}

* In the case of $\mathrm{CO}_{2}$, "high temperature" region also includes the "very high-temperature" region of Table 1.

Under oxidation conditions, the contribution of the carbon monoxide from the paper to that produced from a plain cigarette as a whole is negligible ( 0.7 to $2.5 \%$, Table 1 ), while the carbon dioxide contribution of the paper is small (less than $5 \%$ ).

The amounts of oxides of carbon produced by direct thermal decomposition of tobacco (Table I), plus those produced by oxidation only (Table 5), are compared to those produced by combined decomposition and oxidation when tobacco is heated in air (Table 1) in Table 6. There is no systematic trend, although in general there is more carbon monoxide and more carbon dioxide produced from combined pyrolysis and oxidation than predicted from the separate experiments. This is presumably because of the secondary oxidation of pyrolysis and primaryoxidation products that can occur when tobacco is heated in air.

Table 7 shows the proportion of the oxides of carbon that are produced by thermal decomposition in the high-temperature region $\left(500^{\circ}-1000^{\circ} \mathrm{C}\right)$ under oxidation conditions. This is approximately equal to the proportion of carbon oxides produced by pyrolysis in the combustion coal of a cigarette.

\section{SUMMARY}

Flue-cured Virginia tobacco has been heated in nitrogen and nitrogen/oxygen mixtures under flow conditions, and the rate of formation of carbon monoxide and carbon dioxide has been determined as a function of temperature, heating rate, and proportion of oxygen in the gas.

When the tobacco is heated in nitrogen at heating rates comparable to those in a smouldering cigarette, $27 \%$ of the carbon content of the tobacco is converted to carbon oxides. Both carbon oxides show two distinct formation regions: a low-temperature region (about $100^{\circ}-450^{\circ} \mathrm{C}$ ), and a high-temperature region (about $550^{\circ}-900^{\circ} \mathrm{C}$ ). These temperature limits are almost identical to those predicted from studies on the combustion coal of a cigarette burning in air.

When tobacco, or the carbonaceous residue remaining after the pyrolysis experiments, is heated in nitrogen/ oxygen mixtures, the total amount of carbon converted to carbon monoxide and carbon dioxide is independent of heating rate, but the relative proportions of the two oxides are strongly dependent on heating rate. At the lower heating rate, proportionally less carbon monoxide, and more carbon dioxide, is produced.

Under oxidation conditions, about $70 \%$ of both carbon oxides formed in the low-temperature region $\left(100^{\circ}-450^{\circ} \mathrm{C}\right)$ are produced by tobacco decomposition reactions, whereas in the high-temperature region about $10-20 \%$ of the carbon monoxide, and $2-9 \%$ of the carbon dioxide, are produced by tobacco decomposition.

\section{ZUSAMMENFASSUNG}

Beim Erhitzen von "flue-cured"-Virginia-Tabak in Stickstoff und Stickstoff/Sauerstoff-Gemischen unter Rauchstrom-Bedingungen wurde die Bildung von Kohlenmonoxid und Kohlendioxid in Abhängigkeit von Temperatur, Aufheizgeschwindigkeit und dem Sauerstoffanteil des Gases untersucht.

Wenn der Tabak unter Stickstoff mit Aufheizgeschwindigkeiten erhitzt wird, die denen einer glimmenden Cigarette entsprechen, wird der Kohlenstoffgehalt des Tabaks zu $27 \%$ in Kohlenoxide umgewandelt. Beide Kohlenoxide bilden sich in zwei verschiedenen Regionen: in einer Region mit niedriger Temperatur (etwa $100^{\circ}-450^{\circ} \mathrm{C}$ ) und in einer Region mit hohen Temperaturen (etwa $550^{\circ}-900^{\circ} \mathrm{C}$ ). Diese Temperaturbereiche sind nahezu identisch mit denen, die sich aus Untersuchungen herleiten lassen, welche über die Verkohlung einer in Luft brennenden Cigarette durchgeführt wurden.

Wird Tabak oder der nach der Pyrolyse verbleibende karbonisierte Rückstand in Stickstoff/Sauerstoff-Gemischen erhitzt, so ist die Kohlenstoffmenge, die insgesamt zu Kohlenmonoxid und Kohlendioxid umgewandelt wird, unabhängig von der Aufheizgeschwindigkeit, wobei der jeweilige Anteil der beiden Oxide jedoch in starkem Maße von dieser abhängt. Bei niedrigerer Aufheizgeschwindigkeit bildet sich im Verhältnis weniger Kohlenmonoxid und mehr Kohlendioxid.

Unter Oxydationsbedingungen beruht die Bildung der beiden Kohlenoxide bei etwa $100^{\circ}-450^{\circ} \mathrm{C}$ zu etwa $70 \%$ auf Abbaureaktionen des Tabaks, wohingegen sich in der Zone hoher Temperaturen ungefähr 10-20\% des Kohlenmonoxids und 2-9\% des Kohlendioxids auf die Zersetzung des Tabaks zurückführen lassen.

\section{RESUME}

Du tabac «flue-cured» de Virginie a été chauffé dans de l'azote et dans des mélanges azote/oxygène en régime de flux. La formation du monoxyde et du dioxyde de carbone a été déterminée en fonction de la tempéra- 
ture, de la vitesse de chauffage et de la proportion d'oxygène dans le gaz.

Pour des vitesses de chauffage dans l'azote correspondant à une cigarette qui couve, $27 \%$ de la teneur en carbone du tabac sont convertis en oxydes. Les deux oxydes de carbone ont deux zones de formation distinctes: une zone de basse température (environ $100^{\circ}$ à $450^{\circ} \mathrm{C}$ ) et une zone de haute température (environ $550^{\circ}$ à $900^{\circ} \mathrm{C}$ ). Ces limites de température sont presqu'identiques à celles prédites par des études sur la carbonisation d'une cigarette brûlant à l'air.

Lorsque l'on chauffe du tabac, ou le résidu carbonisé résultant d'une pyrolyse, dans des mélanges azote/ oxygène, la quantité totale de carbone converti en oxydes est indépendante de la vitesse de chauffage, mais la proportion des deux en dépend fortement. Pour une vitesse de chauffage inférieure, la proportion du monoxyde de carbone est proportionellement inférieure à celle du dioxyde.

Dans un milieu oxydant, environ $70 \%$ des oxydes formés dans la zone de basse température $\left(100^{\circ}\right.$ à $450^{\circ} \mathrm{C}$ ) sont produits par des réactions de décomposition du tabac, alors que dans la zone de haute température environ to à $20 \%$ du monoxyde et 2 à $9 \%$ du dioxyde seulement sont produits par la décomposition du tabac.

\section{REFERENCES}

1. Baxter, J. E., and M. E. Hobbs: Tobacco Science 11 (1967) 65 .

2. Baker, R. R., and K. D. Kilburn: Beitr. Tabakforsch. 7 (1973) 79 .

3. Pisklov, W. P., and I. G. Mochnačev: Ber. Inst. Tabakforsch. (Dresden) 1971, 18, 66.
4. Burton, H. R.: Paper presented at 27th Tobacco Chemists' Research Conference, Winston-Salem, N.C., U.S.A., October 1973.

5. Edmonds, M. D., M. T. Core, A. Bavley, and R. F. Schwenker, Jr.: Tobacco Science 9 (1965) 48.

6. Kato, Kunio, Nobuko Takahashi, and Yoichi Kaburaki: Japan Monop. Corp. Central Research Institute Scientific Papers 107 (1965) 165.

7. Burton, H. R., and D. Burdick: Tobacco Science 11 (1967) 180.

8. Stern, E. W., A. S. Logiudice, and H. Heinemann: I. and E. C. Process Design and Development 4 (1965) 171.

9. Newsome, J. R., and C. H. Keith: Tobacco Science 9 (1965) 65.

1.o. Hook, R. G.: Paper presented at Twentieth Tobacco Chemists' Research Conference, Winston-Salem, N.C., U.S.A., November 1966.

11. Field, M. A., D. W. Gill, B. B. Morgan, and P.G.W. Hawksley: In "Combustion of Pulverised Coal", Appendix M, British Coal Utilisation Research Association, Leatherhead, 1967.

\section{Acknowledgements}

Thanks are due to Mr. B. G. Bunn for technical assistance, to Mr. J. M. Davey for computation of some of the results, and to Dr. K. D. Kilburn for critical discussion.

The author's address:

Group Research and Development Centre, British-American Tobacco Co. Ltd., Regent's Park Road, Southampton, SO 9 IPE, England. 